\title{
MULTI- CRITERIA DECISION BASED APPROACH TO SELECTING THE TYPE OF INDUSTRIAL HALLS USED IN FOOD INDUSTRY
}

\section{Ozrislava Milinkovićl, Branislav Jakić2 , Slobodan Vuksanović3 ,Dragana Macura ${ }^{4}$, Milica Šelmič}

\begin{abstract}
Design of production facility in food industry covers all stages of its development, from concept and selection of technological processes to the construction and putting facility in to operation. The objectives pursued in the selection and construction of multipurpose industrial facility is reducing costs as well as the negative impact that the building has on the environment. In other words objectives are connecting engineering theory and practice, in order to achieve savings in the use of resources necessary for the construction, reducing costs of maintenance and usage of the facility from the perspective of the whole life cycle. Introducing the concept of sustainability in food industry must start from choosing sustainable plant where food is processed, packed and stored. This is important because in a polluted environment is not possible to produce high-quality food. Applying multi-criteria decision methods is enabling us to objectively evaluate the impact that industrial buildings used in the food industry have on the environment, as well as their ability to meet production and environmental criteria. The paper is devoted to an analysis of commonly used industrial halls in food industry and building systems in terms of environmental protection and sustainable development.
\end{abstract}

1 Ozrislava Milinković Ph.D., University Business Academy Novi Sad, Faculty for Applied Management Economic and Finance, Nemanjina 4, 11000 Belgrade, Serbia +381 11 2643390, E-mail: ozradjurovic@yahoo.com

2 Branislav Jakić Ph.D., Full Professor, University Business Academy Novi Sad, Faculty for Applied Management Economic and Finance, Nemanjina 4, 11000 Belgrade, Serbia+381 11 2643390,E-mail: branislav.jakic@mef.edu.rs

3 Slobodan Vuksanović Ph.D., Assistant Professor,University Business Academy Novi Sad, Faculty for Applied Management Economic and Finance, Nemanjina 4, 11000 Belgrade, Serbia+381 11 2643390,E-mail: jassnna@yahoo.com

4 Dragana Macura Ph.D., Assistant Professor, Belgrade University, Faculty of Transport and Traffic Engineering, Vojvode Stepe 305, 11000 Belgrade, Serbia,+381 11 3091286, E-mail: d.macura@sf.bg.ac.rs

5 Milica Šelmić Ph.D., Assistant Professor, Belgrade University, Faculty of Transport and Traffic Engineering, Vojvode Stepe 305,11000 Belgrade, Serbia,+381 11 3091286, E-mail: m. selmic@sf.bg.ac.rs

EP 2017 (64) 1 (81-96) 
Key words: multipurpose industrial halls, environmental protection, sustainable development, multi-criteria decision method - analytical hierarchy process.

JEL: L74, Q01, Q40, Q50

\section{Introduction}

The Industrial Revolution and the development of mass production led to an increase in living standards and to progress in almost all aspects of human life. Development of the industry led to urbanization, economic and social prosperity, mass food production and increase in population. Development of new technologies has strongly reflected in the agriculture and food industry .Use of pesticides and fertilizers has enabled the creation of more abundant food supply while chemists and chemical engineers contributed food to be higher in quality and testier. However, human progress has come at the great price to environment. Increase in population inevitably led to increased exploitation of resources, deforestation, and emission of carbon dioxide, pollution of water, air and waste generation. Depletion of resources and growing environmental pollution triggered the reaction of experts to review the relationship between people and nature and to introduce the concept of "sustainability" in all aspects of human activity.

\section{Methodology}

In the paper relevant literature was used and the realistic data regarding initial cost of building construction, speed of construction, cost of maintenance for the period of 60 years, thermal losses, energy used for manufacturing construction material, mechanical resistance and stability of the building, noise protection, lifespan of the building, possibility of recycling, emission of harmful substances and radiation from materials and fire resistance. Analysis of the data was performed using multi-criteria decision-making method Analytic Hierarchy Process (AHP), with purpose of selecting the type of multipurpose industrial facility (hall) used in the food industry which will be cost effective while respecting environmental criteria.

\section{Problem of selecting type of industrial hall used in the food industry}

Selecting the type of industrial hall is a complex process because the selection criteria are often contradictory as well as interests of participants in decision-making process. Criterions that are most commonly conflicted are the initial price of the construction and impact on the environment. It is not uncommon that objects that have a low or lower initial construction costs have very high cost of maintenance and exploitation that can exceed the initial cost of construction several times as well as being environmentally unfriendly, over-consuming natural resources and therefore are not sustainable. In practice the main selection criteria of investment is the initial cost of construction without considering the cost of maintenance, cost of exploitation the exploitation and environmental impacts through the entire life cycle of the object.

Multi-criteria decisions making processes is applied to the important strategic decisions when there are a large number of criteria needed to be taken in to account as well as a large number of stakeholders (decision makers) with conflicted value systems. Multi-criteria decisions 
making processes and its methods can greatly improve the decision-making process and contribute to a more detailed and more accurate comparative analysis of infrastructure facilities by various criteria, such as economic and ecological. The proposed "best solution" has a good chance to be accepted as a good compromise between the various conflicting interests of participants in decision making process. Such methodological approach can lead to significant financial savings, reduced environmental pollution, resource consumption and faster integration into the European standards.

Belgrade region has a significant land potential of about 221 thousand hectares of agricultural land, which makes $68 \%$ of the total territory of Belgrade (Belgrade chamber of industry and commerce, 2015). Available land has significant capacity for the cultivation and processing of basic agricultural products, which is a good basis for the development of food industry. Development of food industry requires the construction of industrial facilities for the processing, storage, packaging and distribution of agricultural products. To assess the impact of industrial facilities on the environment and human health it is necessary to consider all phases of construction including the use of natural raw materials for the manufacture of building products of the construction method, the use of object-hall and eventually demolition and recycling. The construction is considered to be an activity that consumes the greatest amount of natural resources, requires high energy consumption during construction of multipurpose industrial buildings, as well as the operation of facilities (heating, cooling, and lighting) which is directly related to the emission of carbon dioxide and greenhouse gases.

In order to select the most sustainable industrial building-hall, analysis was conducted on the four most frequently built industrial halls used in the food industry:

- $\quad$ A1 - steel hall with sandwich panels,

- $\quad$ A2 - classic brick hall with a steel roof,

- $\quad$ A3 - prefabricated halls of reinforced concrete elements and

- $\quad$ A4 - prefabricated halls of ferrocement sandwich elements.

For the assessment of the sustainability and profitability of multifunctional industrial halls the following criteria has been taken in consideration: initial cost of building construction, speed of construction, cost of maintenance for the period of 60 years, thermal losses, energy used for manufacturing construction material, mechanical resistance and stability of the building, noise protection, lifespan of the building, possibility of recycling, emission of harmful substances and radiation from materials and fire resistance.

Based on realistic data from the practice properties of materials used and construction of buildings following calculations have been made:

X1 - Initial cost of building construction. The value of construction objects can be expressed through the total cost and over the unit of measurement of the constructed object. In Serbia it is common practice that $\mathrm{m}^{2}$ is used as unit of measurement of built space. Cost calculations include only construction without finishing works and furnishing of the object. Values are defined according to the current offers of contractors. 
Table 1. Average price of industrial halls $€ / \mathrm{m}^{2}$

\begin{tabular}{|c|c|}
\hline Type of hall & Average price $€ / \mathrm{m}^{2}$ \\
\hline Steel hall with "sandwich" panel & 210 \\
\hline Hall made of bricks with steel roof & 320 \\
\hline Prefabricated hall made from reinforced concrete (AB) & 380 \\
\hline Prefabricated ferrocement (FC) & 290 \\
\hline
\end{tabular}

Source: Authors' research

X2 - The speed of construction. It is measured with the number of days required to build facility. Speed of construction depends largely on the construction technology. Construction technology can be classified into: a traditional construction, improved traditional construction, industrialized construction and prefabrication.

Table 2.Speed of construction measured in working days

\begin{tabular}{|l|c|}
\hline \multicolumn{1}{|c|}{ Type of hall } & $\begin{array}{c}\text { Speed of construction measured in } \\
\text { working days }\end{array}$ \\
\hline Steel hall with "sandwich" panel & 60 \\
\hline Hall made of bricks with steel roof & 120 \\
\hline Prefabricated hall made from reinforced concrete (AB) & 45 \\
\hline Prefabricated ferrocement (FC) & 45 \\
\hline
\end{tabular}

Source: Authors' research

X3 - Maintenance costs for a period of 60 years. Maintenance is a process which ensures that a building or its parts are functional to use. Maintenance ensures safety, functionality and maintains the value of the property and its quality. In The Law on Planning and Construction of the Republic of Serbia are given two types of maintenance: investment and ongoing maintenance. Investment maintenance is performing construction or other works, depending on the type of object in order to improve condition during exploitation of the facility (Law on planning and construction article 2-36).

The current (regular) maintenance is performing the in order to prevent any damage caused by the use of the object or with the purpose of eliminating such damage and its consisting of inspection, repairs and taking preventive and protective measures, and all other works which provides a satisfactory level of usability (Law on planning and construction article 2-36a). 
Table 3. Steel hall with "sandwich panels" - Maintenance cost calculated in Euros

\begin{tabular}{|c|c|c|c|c|c|c|c|c|c|c|}
\hline No. & Steel hall & Unit & $\begin{array}{l}\text { Qt. } \\
\text { /No. } \\
\text { work }\end{array}$ & Period & $\begin{array}{l}\text { Times in } \\
60 \text { years }\end{array}$ & Pack & $\begin{array}{c}\text { Price } \\
\text { pack. / } \\
\text { no. Days }\end{array}$ & $\begin{array}{c}\text { Spending } \\
/ \text { hours } \\
\text { days }\end{array}$ & $\begin{array}{l}\text { Price } \\
\text { unit. }\end{array}$ & Total \\
\hline \multirow[t]{2}{*}{1} & Paint steel & $\mathrm{m}^{2}$ & 742.29 & 10 & 5 & 51 & 25 & $1 \mathrm{l} / 8 \mathrm{~m}^{2}$ & 0.625 & $2,319.66$ \\
\hline & Work & $\mathrm{h}$ & 6 & & 5 & & 10 & 10 & 2.5 & $7,500.00$ \\
\hline \multicolumn{2}{|c|}{ work patform } & $\mathrm{h}$ & 1 & & 5 & & 10 & 10 & 20 & $10,000.00$ \\
\hline \multirow[t]{3}{*}{2} & \begin{tabular}{|l|} 
The ridge \\
\end{tabular} & $\mathrm{m}$ & 1,405 & 15 & 3 & $6 m$ & 8 & & 1.33 & $5,620.00$ \\
\hline & The sealant & $\mathrm{m}$ & 1,405 & 15 & 3 & $600 \mathrm{ml}$ & 10 & $50 \mathrm{ml} / \mathrm{m}$ & 0.83 & $3,512.50$ \\
\hline & \begin{tabular}{r|} 
work \\
\end{tabular} & $\mathrm{h}$ & 12 & & 3 & & 10 & 10 & 2.5 & $9,000.00$ \\
\hline \multicolumn{2}{|c|}{ work platform } & $\mathrm{h}$ & 1 & & 3 & & 10 & 10 & 20 & $6,000.00$ \\
\hline 3 & Roof panel & $\mathrm{m}^{2}$ & 672 & 40 & 1 & pcs & & & 26 & $17,472.00$ \\
\hline \multicolumn{2}{|c|}{ work platform } & $\mathrm{h}$ & 6 & & 5 & & 10 & 10 & 3 & $9,000.00$ \\
\hline & crane & $\mathrm{h}$ & 1 & & 5 & & 10 & 5 & 50 & $12,500.00$ \\
\hline \multirow[t]{2}{*}{4} & gutters & $\mathrm{m}$ & 138 & 25 & 2 & $\mathrm{~m}$ & & & 4 & $1,104.00$ \\
\hline & work & $\mathrm{h}$ & 3 & & 2 & & 5 & 10 & 3 & 900.00 \\
\hline \multicolumn{2}{|c|}{ work platform } & $\mathrm{h}$ & 1 & & 2 & & 5 & 10 & 20 & $2,000.00$ \\
\hline
\end{tabular}

\begin{tabular}{|r|c|}
\hline total for 60 years & $\mathbf{8 6 , 9 2 8 . 1 6}$ \\
\hline for $/ \mathrm{m} 2$ yearly & $\mathbf{1 . 8 8}$ \\
\hline
\end{tabular}

Source: Authors' research

Table 4. Hall made of bricks with steel roof - Maintenance cost calculated in Euros

\begin{tabular}{|c|c|c|c|c|c|c|c|c|c|c|}
\hline No. & $\begin{array}{l}\text { Hall from } \\
\text { bricks }\end{array}$ & Unit & $\begin{array}{l}\text { Qt. } \\
\text { /No. } \\
\text { work }\end{array}$ & Period & $\begin{array}{l}\text { Times in } \\
60 \text { years }\end{array}$ & Pack & $\begin{array}{c}\text { Price } \\
\text { pack. / } \\
\text { no. Days }\end{array}$ & $\begin{array}{c}\text { Spending } \\
\text { / hours } \\
\text { days }\end{array}$ & $\begin{array}{l}\text { Price } \\
\text { unit. }\end{array}$ & Total \\
\hline 1 & Mortar & $\mathrm{m}^{2}$ & 672 & 50 & 1 & & & & 7 & $4,704.00$ \\
\hline \multirow[t]{2}{*}{2} & $\begin{array}{c}\text { Facade and } \\
\text { facade } \\
\text { paint }\end{array}$ & $\mathrm{m}$ & 672 & 20 & 2 & & & & 4 & $5,376.00$ \\
\hline & work & $\mathrm{h}$ & & & & & & & & 0.00 \\
\hline \multicolumn{2}{|c|}{ work platform } & $\mathrm{h}$ & 1 & & 3 & & 20 & 8 & 20 & $9,600.00$ \\
\hline \multirow[t]{3}{*}{2} & The ridge & $\mathrm{m}$ & 663 & 15 & 3 & $6 m$ & 8 & & 1.33 & $2,652.00$ \\
\hline & The sealant & $\mathrm{m}$ & 663 & 15 & 3 & $100 \mathrm{~m}$ & 25 & $\mathrm{~m}$ & 0.25 & 497.25 \\
\hline & work & $\mathrm{h}$ & 6 & & 5 & & 10 & 10 & 2.5 & $7,500.00$ \\
\hline \multicolumn{2}{|c|}{ work platform } & $\mathrm{h}$ & 1 & & 5 & & 10 & 5 & 20 & $5,000.00$ \\
\hline \multirow[t]{3}{*}{3} & Roof panels & $m^{2}$ & 762 & 40 & 1 & pcs & & & 8 & $6,096.00$ \\
\hline & work & $\mathrm{h}$ & 6 & & 5 & & 10 & 10 & 3 & $9,000.00$ \\
\hline & crane & $\mathrm{h}$ & 1 & & 5 & & 10 & 5 & 50 & $12,500.00$ \\
\hline \multirow[t]{2}{*}{4} & gutters & $\mathrm{m}$ & 138 & 25 & 2 & $\mathrm{~m}$ & & & 4 & $1,104.00$ \\
\hline & work & $\mathrm{h}$ & 3 & & 2 & & 5 & 10 & 3 & 900.00 \\
\hline \multicolumn{2}{|c|}{ work platform } & $\mathrm{h}$ & 1 & & 2 & & 5 & 10 & 20 & $2,000.00$ \\
\hline
\end{tabular}

\begin{tabular}{|r|c|}
\hline total for 60 years & $\mathbf{6 6 , 9 2 9 . 2 5}$ \\
\hline for $/ \mathrm{m} 2$ yearly & $\mathbf{1 . 4 5}$ \\
\hline
\end{tabular}

Source: Authors' research 
Table 5. Prefabricated AB hall - Maintenance cost calculated in Euros

\begin{tabular}{|c|c|c|c|c|c|c|c|c|c|c|}
\hline No. & AB Hall & Unit & $\begin{array}{l}\text { Qt. } \\
\text { /No. } \\
\text { work }\end{array}$ & Period & $\begin{array}{l}\text { Times in } \\
60 \text { years }\end{array}$ & Pack & $\begin{array}{c}\text { Price } \\
\text { pack. / } \\
\text { no. Days }\end{array}$ & $\begin{array}{c}\text { Spending } \\
\text { / hours } \\
\text { days }\end{array}$ & $\begin{array}{l}\text { Price } \\
\text { unit. }\end{array}$ & Total \\
\hline \multirow[t]{2}{*}{1} & $\begin{array}{c}\text { Color } \\
\text { concrete }\end{array}$ & $\mathrm{m}^{2}$ & 672 & 15 & 3 & 51 & 30 & $11 / 4 m^{2}$ & 1.5 & $3,024.00$ \\
\hline & work & $h$ & 6 & & 3 & & 10 & 10 & 2.5 & $4,500.00$ \\
\hline \multicolumn{2}{|c|}{ work platform } & $\mathrm{h}$ & 1 & & 3 & & 10 & 10 & 20 & $6,000.00$ \\
\hline \multicolumn{2}{|c|}{\begin{tabular}{|l|} 
The sealant \\
\end{tabular}} & $\mathrm{m}$ & 1,405 & 15 & 3 & $600 \mathrm{ml}$ & 10 & $50 \mathrm{ml} / \mathrm{m}$ & 0.83 & $3,512.50$ \\
\hline & \begin{tabular}{|r|} 
work \\
\end{tabular} & $\mathrm{h}$ & 12 & & 3 & & 10 & 10 & 2.5 & $9,000.00$ \\
\hline \multicolumn{2}{|c|}{ work platform } & $\mathrm{h}$ & 1 & & 3 & & 10 & 10 & 20 & $6,000.00$ \\
\hline \multirow[t]{2}{*}{3} & \begin{tabular}{|c|} 
POLY- \\
URETHAN
\end{tabular} & $\mathrm{m}^{2}$ & 672 & 15 & 3 & $25 \mathrm{~kg}$ & 130 & $1.5 \mathrm{~kg} / \mathrm{m}^{2}$ & 7.8 & $15,724.80$ \\
\hline & work & $\mathrm{h}$ & 6 & & 3 & & 6 & 10 & 3 & $3,240.00$ \\
\hline \multirow[t]{2}{*}{4} & gutters & $\mathrm{m}$ & 138 & 25 & 2 & $\mathrm{~m}$ & & & 4 & $1,104.00$ \\
\hline & work & $\mathrm{h}$ & 3 & & 2 & & 5 & 10 & 3 & 900.00 \\
\hline \multicolumn{2}{|c|}{ work platform } & $\mathrm{h}$ & 1 & & 2 & & 5 & 10 & 20 & $2,000.00$ \\
\hline
\end{tabular}

Source: Authors' research

Table 6. Prefabricated FC hall - Maintenance cost calculated in Euros

\begin{tabular}{|c|c|c|c|c|c|c|c|c|c|c|}
\hline No. & FC hall & Unit & $\begin{array}{l}\text { Qt. } \\
\text { /No. } \\
\text { work }\end{array}$ & Period & $\begin{array}{l}\text { Times in } \\
60 \text { years }\end{array}$ & Pack & $\begin{array}{c}\text { Price } \\
\text { pack./ } \\
\text { no. Days }\end{array}$ & \begin{tabular}{|c|} 
Spending \\
/ hours \\
days
\end{tabular} & $\begin{array}{l}\text { Price } \\
\text { unit. }\end{array}$ & Total \\
\hline 1 & Mortar & $\mathrm{m}^{2}$ & 213 & 50 & 1 & & & & 7 & $1,491.00$ \\
\hline 2 & $\begin{array}{c}\text { Facade and } \\
\text { façade } \\
\text { color }\end{array}$ & $\mathrm{m}$ & 213 & 20 & 2 & & & & 4 & $1,704.00$ \\
\hline \multicolumn{2}{|c|}{ work platform } & $\mathrm{h}$ & 1 & & 3 & & 8 & 10 & 20 & $4,800.00$ \\
\hline 3 & \begin{tabular}{|c|} 
POLY- \\
URETHAN
\end{tabular} & $\mathrm{m}^{2}$ & 1,217 & 15 & 3 & $25 \mathrm{~kg}$ & 130 & $1.5 \mathrm{~kg} / \mathrm{m}^{2}$ & 7.8 & $28,477.80$ \\
\hline
\end{tabular}

\begin{tabular}{|r|c|}
\hline total for 60 years & $\mathbf{3 6 , 4 7 2 . 8 0}$ \\
\hline for $/ \mathrm{m} 2$ yearly & $\mathbf{0 . 7 9}$ \\
\hline
\end{tabular}

Source: Authors' research

X4 -Energy used for the production of building materials. Construction materials are mainly obtained by processing of raw materials. For the production of building materials it is necessary to spend a certain amount of energy in order to obtain a usable building material from raw materials. Besides greenhouse gas emissions production process often requires a great expenditure of energy (Kreijger, 1979). Production of building materials is responsible for $80 \%$ of energy consumption and the construction process itself is responsible for only $13 \%$ (Gorkum, 2010).For the selection of building materials in addition to functionality, the impact they have on people's health the total energy balance should be taken into account (Hawken, Lovins, Lovins, 2009).It represents the total energy that some construction materials "consume" during the lifetime. 
Table 7. Steel hall with "sandwich panels" - Energy consumption during manufacturing of construction materials

\begin{tabular}{|c|l|c|c|c|r|}
\hline No. & \multicolumn{1}{|c|}{ Description of materials } & $\mathbf{m}^{\mathbf{3}}$ & $\mathbf{t}$ & $\mathbf{k w h} / \mathbf{t}$ & $\mathbf{M w h}$ total \\
\hline 1 & Steel and steel plates & 5.14 & 40.06 & $4,500.00$ & 180.29 \\
\hline 2 & Mineral wool & 148.00 & 17.76 & $6,000.00$ & 106.56 \\
\hline & & & & & $\mathbf{2 8 6 . 8 5}$ \\
\hline
\end{tabular}

Source: Authors' research

Table 8. Hall made of bricks with steel roof - Energy consumption during manufacturing of construction

\begin{tabular}{|c|l|c|r|r|r|}
\hline No. & \multicolumn{1}{|c|}{ Description of materials } & $\mathbf{m}^{\mathbf{3}}$ & \multicolumn{1}{c|}{$\mathbf{t}$} & $\mathbf{k w h} / \mathbf{t}$ & $\mathbf{M w h}$ total \\
\hline 1 & Steel and steel plates & 3.28 & 25.57 & $4,500.00$ & 115.07 \\
\hline 2 & Clay blocks & 156.00 & 109.20 & 832.00 & 90.85 \\
\hline 3 & AB,MB30 & 18.00 & 48.60 & $1,050.00$ & 51.03 \\
\hline 4 & Mineral wool & 159.58 & 19.15 & $6,000.00$ & 114.90 \\
\hline & & & & $\mathbf{3 7 1 . 8 5}$ \\
\hline
\end{tabular}

Source: Authors' research

Table 9. Prefabricated FC and AB halls - Energy consumption during manufacturing of construction

\begin{tabular}{|c|c|c|}
\hline Description of materials & $\begin{array}{c}\text { Prefabricated FC hall } \\
\text { dimensions 48x17 }\end{array}$ & $\begin{array}{c}\text { Prefabricated AB hall } \\
\text { dimensions 48x17 }\end{array}$ \\
\hline Mwh & Mwh \\
\hline Cement and steel & 166.79 & 242.99 \\
\hline Extruded polystyrene & 110.84 & 117.31 \\
\hline ToтalMwh & $\mathbf{2 7 7 . 6 3}$ & $\mathbf{3 6 0 . 3 0}$ \\
\hline
\end{tabular}

Source: Authors' research

$X 5$ - Thermal losses. Thermal transience also known as the "U" -value, is the rate of heat transfer and is measured in watts through one square meter of the building divided by the difference in temperature across the structure. It is expressed in watts per square meter (W / $\mathrm{m}^{2} \mathrm{~K}$ ). The thermal transience of most of the walls and roofs can be calculated using the ISO 6946 standards; unless there are metal bridges to bridge the insulation in which case can be calculated using the ISO 10211 standards. ISO 6946 is the method of calculating the thermal resistance and thermal conductivity of construction components and building elements, excluding doors windows and other components through which air flows is provided and heat transfer in the ground (ISO 6946:2007). The characteristics of heat transfer depend on each structural element of the thermal conductivity of the material used, the thickness of the various components, geometric structure (straight, curved walls) as well as environmental conditions. The term "heat transfer loss" is a term used to describe the ability of the building envelope to save energy which is very important in assessing the energy efficiency of the 
building. Construction objects are responsible for $40 \%$ of total energy consumption in all European Union member states (Poel, Cruchten, Balaras, 2007).

Table 10. Thermal losses for analyzed halls

\begin{tabular}{|c|c|c|c|c|c|c|c|c|c|c|c|c|c|c|}
\hline \multicolumn{2}{|r|}{ Type of hall } & & \multicolumn{3}{|c|}{ Steel hall with "sandwich" panel } & \multicolumn{3}{|c|}{ Hall made of bricks with steel roof } & \multicolumn{3}{|c|}{ RC hall } & \multicolumn{3}{|c|}{ FC hall } \\
\hline No. & SURFACES & c & $\mathrm{m}^{2}$ & $\mathrm{w} / \mathrm{m}^{2} \mathrm{~K}$ & w & \begin{tabular}{|l|}
$\mathrm{m}^{2}$ \\
\end{tabular} & $\mathrm{w} / \mathrm{m}^{2} \mathrm{~K}$ & w & $\mathrm{m}^{2}$ & $\mathrm{w} / \mathrm{m}^{2} \mathrm{~K}$ & w & $\mathrm{m}^{2}$ & $\mathrm{w} / \mathrm{m}^{2} \mathrm{~K}$ & w \\
\hline 1 & Outer window - vertical wall & 1 & \begin{tabular}{l|l}
163 \\
\end{tabular} & \begin{tabular}{|l|}
3.1 \\
\end{tabular} & $19,201.40$ & 163 & \begin{tabular}{|r|}
3.1 \\
\end{tabular} & $19,201.40$ & 163 & $\begin{aligned} 3.1 \\
\end{aligned}$ & $19,201.40$ & 19.2 & 3.1 & $2,261.76$ \\
\hline 2 & Outer window - roof & 1 & & 3.1 & & & 3.1 & & & 3.1 & & 42.2 & 3.1 & $4,971.16$ \\
\hline 3 & Outer vertical wall & 1 & 672.77 & 0.39 & $9,970.51$ & 672.77 & 0.27 & $6,902.66$ & 672.77 & 0.25 & $6,391.35$ & 213.03 & 0.26 & $2,104.78$ \\
\hline 4 & Roof & 1 & 768.84 & 0.39 & $11,394.21$ & 768.84 & 0.39 & $11,394.21$ & 768.84 & 0.25 & $7,303.98$ & 1217 & 0.29 & $13,411.33$ \\
\hline 5 & Floor & 0.5 & 768.84 & 0.29 & $8,472.62$ & 768.84 & 0.29 & $8,472.62$ & 768.84 & 0.29 & $8,472.62$ & 768.84 & 0.29 & $8,472.62$ \\
\hline 6 & Surface of outer layer & $\mathrm{m}^{2}$ & & $2,373.45$ & & & $2,373.4$ & & & $2,373.4$ & & & $2,260.2$ & \\
\hline 7 & Volume of the object & $\mathrm{m}^{3}$ & & $5,190.44$ & & & $5,190.4$ & & & $5,190.4$ & & & $5,190.4$ & \\
\hline 8 & Factor of the specific shape & c & & 0.46 & & & 0.46 & & & 0.46 & & & 0.44 & \\
\hline 9 & Transmission loss & $\mathrm{w}$ & & $49,038.7$ & & & $45,970.8$ & & & 41,369 . & & & 31,221 . & \\
\hline 10 & Specific transmission losses & $\mathrm{W} / \mathrm{m}^{3}$ & & 9.45 & & & 8.86 & & & 7.97 & & & 6.02 & \\
\hline
\end{tabular}

Source: Authors' research

X6 - Total $\mathrm{CO}_{2}$ emissions during the manufacturing of construction materials. During the manufacturing and processing of building materials, the environment is polluted in several different ways (Cole, 1998). One of the most alarming is through the emission of harmful gases especially carbon dioxide $\left(\mathrm{CO}_{2}\right)$. Construction materials are responsible for $75 \%$ of the total carbon dioxide emissions during the construction of the facility (Flower, Sanjayan, 2007).Based on values for emission of $\mathrm{CO}_{2}$ for usual and alternative materials calculation has been made of total $\mathrm{CO}_{2}$ emission during the manufacturing of construction materials for analyzed halls.

Table 11. Steel hall with "sandwich panels" - Total $\mathrm{CO}_{2}$ emission

\begin{tabular}{|c|l|c|c|c|r|}
\hline No. & \multicolumn{1}{|c|}{$\begin{array}{c}\text { Description of } \\
\text { materials }\end{array}$} & $\mathrm{m}^{3}$ & $\mathrm{t}$ & $\mathrm{CO}_{2} \mathrm{~kg} / \mathrm{t}$ & $\mathrm{CO}_{2}(\mathrm{t})$ total \\
\hline 1 & Steel and steel plates & 5.14 & 40.06 & $1,720.00$ & 68.91 \\
\hline 2 & Mineral wool & 148.00 & 17,76 & $1,100.00$ & 19.54 \\
\hline & & & & & $\mathbf{8 8 . 4 5}$ \\
\hline
\end{tabular}

Source: Authors' research

Table 12. Hall made of bricks with steel roof - Total $\mathrm{CO}_{2}$ emission

\begin{tabular}{|c|l|c|r|r|r|}
\hline No. & Description of materials & $\mathrm{m}^{3}$ & \multicolumn{1}{c|}{$\mathrm{t}$} & $\mathrm{CO}_{2} \mathrm{~kg} / \mathrm{t}$ & \multicolumn{1}{c|}{$\mathrm{CO}_{2}(\mathrm{t})$ total } \\
\hline 1 & Steel and steel plates & 3.28 & 25.57 & $1,720.00$ & 43.98 \\
\hline 2 & Clay blocks & 156.00 & 109.20 & 114.00 & 12.45 \\
\hline 3 & AB,MB30 & 18.00 & 48.60 & 370.00 & 17.98 \\
\hline 4 & Mineral wool & 159.60 & 19.15 & $1,100.00$ & 21.07 \\
\hline & & & & $\mathbf{9 5 , 4 7}$ \\
\hline
\end{tabular}

Source: Authors' research 
Table 13. $\mathrm{AB}$ and $\mathrm{FC}$ halls - Total $\mathrm{CO}_{2}$ emission

\begin{tabular}{|l|c|c|}
\hline \multicolumn{1}{|c|}{ Description of materials } & $\begin{array}{c}\text { Prefabricated FC hall } \\
\text { dimensions } 4 \mathbf{8 x \mathbf { 1 7 }}\end{array}$ & $\begin{array}{c}\text { Prefabricated } \mathbf{A B} \text { hall } \\
\text { dimensions } \mathbf{4 8} \boldsymbol{x} \mathbf{1 7}\end{array}$ \\
\hline & $\mathbf{C O}_{2}(\mathbf{t})$ & $\mathbf{C O}_{2}(\mathbf{t})$ \\
\hline Cement and steel & 75.06 & 103.95 \\
\hline Extruded polystyrene & 12.21 & 12.93 \\
\hline Total emission of $\mathrm{CO}_{2}(\mathbf{t})$ & $\mathbf{8 7 . 2 8}$ & $\mathbf{1 1 6 . 8 8}$ \\
\hline
\end{tabular}

Source: Authors' research

$\mathrm{X} 7$ - The emission of harmful substances and radiation from materials. Emission of harmful substances that are occurring as a result of production, exploitation, and destruction of building materials are negatively affecting both human health and the environment (Costner, 2005). State authorities are continuously studying different types of chemical additives used for creating and improving performance of construction materials. Many are rated as extremely toxic and even carcinogenic. Some of the most commonly used building materials include polyvinyl chloride (PVC), formaldehyde, radon and crystalline silicon.

- Steel hall with sandwich panels - sandwich panels are coated with "PVC" film to ensure water resistance. This coating to a lesser extent emits toxic fumes in the form of gas dioxin. According to the criteria emission of harmful substances and radiation from materials, this hall could be assessed as "average".

- Hall made of bricks with steel roof-In the composition of this hall all natural materials are included such as clay blocks and mortar. Hollow clay blocks are made of bricks which in small quantities are releasing toxic gas radon. According to the criteria of emission of harmful substances and radiation from the material, this hall could be assessed as "average".

- $\quad \mathrm{AB}$ Prefabricated halls - In the composition of this hall next to the cement and mineral wool insulation that does not come in contact with the end user, are all natural materials which are not hazardous to human health. According to the criteria of radiation harmful substances from the material, this hall was assessed as "good".

- $\quad$ FC Prefabricated halls - In the composition of this hall next to the cement and steel and polystyrene is included. All this materials are not hazardous to human health. According to the criteria of radiation harmful substances from the material, this hall was assessed as "good".

X8 - Resistance to fire. DIN 4102 is widely accepted and used, German standard which describes the fire resistance properties of materials (DIN 4102-2).For the purpose of testing, materials are exposed to direct flame and then the rate of burning is measured. According to this standard, materials are classified as follows: 
Table 14. Fire resistance expressed in minutes

\begin{tabular}{|l|c|}
\hline \multicolumn{1}{|c|}{ Type of hall } & Fire resistance expressed in minutes \\
\hline Steel hall with "sandwich" panel & 30 \\
\hline Hall made of bricks with steel roof & 30 \\
\hline Prefabricated hall made from reinforced concrete (AB) & 90 \\
\hline Prefabricated ferrocement (FC) & 120 \\
\hline
\end{tabular}

Source: Authors' research

X9 - Protection against noise. Environmental noise is unwanted or harmful sound (Law on noise protection in the environment article 3-1). The only obstacle between the people and the noise lies in the construction techniques, materials, and in creating physical barriers which reduces the sound energy to the allowable limit in the relevant areas. Sound protection is realized by choosing suitable design of the facility, performing sound insulation and mitigation measurement, or noise limitations (Law on noise protection in the environment article 3-17). Sound insulation is managed in the facility by implementing architectural - building measures that prevent the transmission of sound from one room to another after broadcasting with aimed to prevent the transmission of sound as much as possible. The goal is to reduce the noise that users of object can hear to the acceptable level. The unit of measurement which expresses the sound level is the decibel. The calculation is based on the properties of exterior walls and materials they are made from and it's carried out by the Faculty of civil engineering. In their work Antalova and Minarovièová (2003) are showing acoustic properties of homogeneous and composite elements. Based on these data following values have been defined:

Table 15. Noise protection values for analyzed halls

\begin{tabular}{|l|c|}
\hline \multicolumn{1}{|c|}{ Type of hall } & Noise protection expressed in dB \\
\hline Steel hall with "sandwich" panel & 32 \\
\hline Hall made of bricks with steel roof & 61 \\
\hline Prefabricated hall made from reinforced concrete (AB) & 72 \\
\hline Prefabricated ferrocement (FC) & 64 \\
\hline
\end{tabular}

Source: Authors' research

X10 - Mechanical resistance and stability of the building. The mechanical stability of the object can be static and dynamic. Static stability implies that the structure must be designed in a way that during the process of construction and usage does not crash deform or any other kind of structural damage does not occur. Dynamic stability implies that the structure must be designed so that due to the effect of natural forces such as earthquakes, wind or load due to the snows does not come to collapsing of the object. 
Table 16. Mechanical stability and resistance values for analyzed halls

\begin{tabular}{|l|c|}
\hline \multicolumn{1}{|c|}{ Type of hall } & $\begin{array}{c}\text { Mechanical stability and resistance } \\
\text { expressed in } \mathbf{M P a}\left(\mathbf{N} / \mathbf{m m}^{\mathbf{2}}\right)\end{array}$ \\
\hline Steel hall with "sandwich" panel & 0.07 \\
\hline Hall made of bricks with steel roof & 3.5 \\
\hline Prefabricated hall made from reinforced concrete (AB) & 10 \\
\hline Prefabricated ferrocement (FC) & 30 \\
\hline
\end{tabular}

Source: Authors' research

X11 - The lifespan of the facility. The life span of the building structure can be described by:

- $\quad$ Technical lifetime is the period in which the construction element or structure is able to fulfill its intended function.

- $\quad$ Functional lifetime refers to the time period in which the objects fulfill the purpose of its aim and expectations of users in accordance with applicable standards and regulations.

- $\quad$ Economic life of the building structure is the period in which the costs of its operation and maintenance are within the planned cost.

Table 17. Life spam of halls expressed in years

\begin{tabular}{|l|c|}
\hline \multicolumn{1}{|c|}{ Type of hall } & Life spam of halls expressed in years \\
\hline Steel hall with "sandwich" panel & 30 \\
\hline Hall made of bricks with steel roof & Up to 50 \\
\hline Prefabricated hall made from reinforced concrete (AB) & Over 100 \\
\hline Prefabricated ferrocement (FC) & Over 100 \\
\hline
\end{tabular}

Source: Authors' research

X12 - Possibility of recycling. Construction industry is responsible for almost $40 \%-50 \%$ of solid waste produced in the European Union yearly (Sterner, 2002). After demolishing a construction object behind it remains building materials such as concrete, wood, glass, metal structures and other. With recycling of these materials their processing and re-use reduces the negative impact of environmental contamination occurring during the production of new material. The recycling reduces the amount of waste and use of natural resources, recycling and reuse of materials reduces the energy and thus emissions of carbon dioxide that is emitted into the air during excavation of raw materials from nature and it's processing (PerezLombard, Ortiz, Pout, 2008).

- Steel hall with "sandwich" panels - Steel is material very suitable for recycling while the sandwich panels cannot be recycled due to the filling of mineral wool, which can harm human health. Evaluation of recyclability is "average".

- Hall made of bricks with steel roof- Steel reinforcement and concrete forming part of this hall can be very successfully recycled while facade and insulation materials from mineral wool are not suitable for recycling. Evaluation of recyclability is "average". 
- $\quad$ Prefabricated reinforced concrete hall (AB) -Reinforced concrete that majority work became part of this hall can be recycled as insulation material polystyrene. Rating recyclability is "very good."

- Prefabricated ferrocement halls (FC) Even though the whole building consists of reinforced concrete, reinforcement method is very specific and the armature is difficult to disentangle from concrete which prevents completely recyclable. Insulating filling is polyurethane that can be recycled. Rating recyclability is "very good."

\section{Multi- criteria decision based approach used - Analytical Hierarchy Process}

Multi criteria decision making process represents one of the most important nonmonetary analysis of today (Papadopoulos,Karagiannidis, 2008) and analysis suitable for evaluation of construction projects and their impact on the environment (San-Jose,Cuadrado, 2010). Analytical hierarchy process (AHP) is one of the most used multi-criteria approaches to scenario analysis and decision-making with consistent evaluation of elements criteria and alternative (Saaty, 1980). AHP is a decision support system. A specific tool for the analysis of the hierarchy of the system, which by evaluating system elements in pairs in relation to the elements of the upper-level hierarchy level, is helping decision makers in the decision process.

AHP allows interactive analysis of the sensitivity of the evaluation process. In addition to this advantage, during the evaluation of elements it checks the consistency of reasoning and decision-makers examine the validity of the obtained rankings of alternatives and criteria, as well as their weight values (Saaty, 1986). AHP approach can treat both quantitative and qualitative attributes of alternatives.

AHP has been applied in various fields of strategic management, where decisions have far-reaching significance. Significance and validity of the scientific basis of this approach is confirmed by the numerous scientific papers and dissertations in which this approach is studied in detail and upgraded. Several scientific conferences dedicated only AHP approach, further confirming its quality and timeliness.

The hierarchy consists of a goal, which is at the top, and he is not compared with any other element of the system; then follows the second level - the criteria to be compared to each other in pairs in relation to the target. If there are sub criteria, they are mutually comparable in relation to each criterion, to which they belong. Finally, the alternatives are compared in relation to the criteria. So, at each hierarchical level elements are compared in relation to the elements of the upper-level.

\section{Application of analytical hierarchy process and analysis of results}

In this paper model was developed to select the type of industrial buildings - halls used in the food industry. The aim of this multi-criteria model is to maximize the profitability of the hall for the entire life cycle of the facility. Total of twelve relevant criterion has been defined, and the four alternatives, as discussed in the previous section. The developed model is graphically represented in the following figure. 
Table18. Values of alternatives as per selected criterions

\begin{tabular}{|c|c|c|c|c|c|c|c|c|c|c|c|c|c|}
\hline & & $\begin{array}{c}\text { Initial cost of } \\
\text { construction }\end{array}$ & $\begin{array}{c}\text { Speed of } \\
\text { construction }\end{array}$ & $\begin{array}{c}\text { Thermal } \\
\text { losses }\end{array}$ & \begin{tabular}{|c|} 
Energy \\
needed for \\
production \\
of \\
construction \\
materials
\end{tabular} & \begin{tabular}{|c} 
Cost of \\
maintananc \\
e for the \\
period of 60 \\
yrs
\end{tabular} & \begin{tabular}{|c|} 
Total \\
emission of \\
co $^{2}$ in \\
production \\
of \\
construction \\
materials \\
\end{tabular} & $\begin{array}{c}\text { Fire } \\
\text { resistance }\end{array}$ & \begin{tabular}{|c|} 
Emission of \\
harmful \\
substances \\
and \\
radiation \\
from \\
materials \\
\end{tabular} & \begin{tabular}{|c} 
Sound \\
protection \\
from air- \\
outside (Rw)
\end{tabular} & $\begin{array}{c}\text { Mechanical } \\
\text { stability and } \\
\text { resistance }\end{array}$ & Life span & Recycling \\
\hline & Description & eur $/ \mathrm{m}^{2}$ & work.day & $\mathrm{w} / \mathrm{m}^{3}$ & kwh & eur $/ \mathrm{m}^{2}$ & \begin{tabular}{l|}
$t$ \\
\end{tabular} & minutes & 5 pointsdesc. & dB & MPa. $\left(\mathrm{N} / \mathrm{mm}^{2}\right.$ & years & 5 points desc \\
\hline Steel hall with sandwich panels & & 210 & 60 & 9.45 & 286.85 & 1.88 & 88.45 & 30 & average & 32 & 3.5 & 40 & average \\
\hline Hall made from bricks with steel roof & & 320 & 120 & 8.86 & 371.85 & 1.45 & 95.47 & 30 & average & 61 & 10 & 50 & good \\
\hline Prefabricated AB hall & & 380 & 45 & 7.97 & 360.30 & 1.19 & 116.88 & 120 & good & 72 & 30 & 100 & very good \\
\hline Prefabricated FC hall & & 290 & 45 & 6.02 & 277.63 & 0.79 & 87.28 & 120 & good & 64 & 34 & 100 & good \\
\hline
\end{tabular}

Source: Authors' research

Figure 1. AHP model

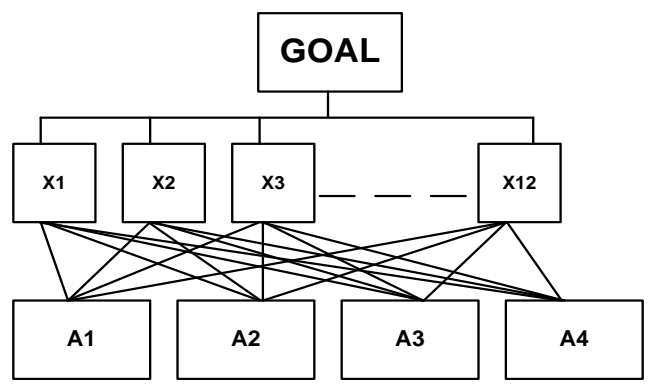

Source: Authors' research

In the developed model some criterions are "cost" type such as: initial cost of construction, speed of construction, thermal losses, maintenance costs, energy needed for production of construction materials, total emission of carbon dioxide during the production of construction materials emission of harmful substances and radiation from materials; and some are "benefit" type: fire resistance, possibility of recycling, noise reduction, mechanical stability and resistance, life cycle cost of object. "Cost" type criterions we wish to minimize while "benefit" type criterions we wish to maximize.

To define final rang of alternatives it is necessary to define relative weight of criterions. To the first criterion "initial cost of construction" double values is given compared to the other criterions which are of the same value. The reason behind such defining of a relative weight of criterions and giving priority to the first criterion compared to the others, is the fact that in practice it is price that is breaking factor in selecting type of industrial hall.

Table 19. Weights of criterions

\begin{tabular}{|c|c|c|c|c|c|c|c|c|c|c|c|c|}
\hline Criterions & $\mathrm{X} 1$ & $\mathrm{X} 2$ & $\mathrm{X} 3$ & $\mathrm{X} 4$ & $\mathrm{X} 5$ & $\mathrm{X} 6$ & $\mathrm{X} 7$ & $\mathrm{X} 8$ & $\mathrm{X} 9$ & $\mathrm{X} 10$ & $\mathrm{X} 11$ & $\mathrm{X} 12$ \\
\hline $\begin{array}{c}\text { Relative } \\
\text { weights }\end{array}$ & 0.15 & 0.08 & 0.08 & 0.08 & 0.08 & 0.08 & 0.08 & 0.08 & 0.08 & 0.08 & 0.08 & 0.08 \\
\hline
\end{tabular}

Source: Authors' research 
Next table represents final rang of halls and relative weights of alternatives. Calculation has been made after implementation of AHP multi-criteria decision support model.

Table 20. Final ranking of calculated results

\begin{tabular}{|l|l|l|}
\hline \multicolumn{1}{|c|}{ Alternatives } & $\begin{array}{c}\text { Relative weight of } \\
\text { alternatives }\end{array}$ & $\begin{array}{l}\text { Final ranking } \\
\text { of alternatives }\end{array}$ \\
\hline Steel hall with "sandwich" panel & 0.155 & 3 \\
\hline Hall made of bricks with steel roof & 0.144 & 4 \\
\hline Prefabricated hall made from reinforced concrete (AB) & 0.301 & 2 \\
\hline Prefabricated ferrocement (FC) & 0.401 & 1 \\
\hline
\end{tabular}

Source: Authors' research

\section{Conclusion}

Application of the Analytic Hierarchy Process (AHP) method for decision support enabled the objective decision of selecting the type of multipurpose industrial facility (hall) used in the food industry. We analyzed four types of most commonly built industrial halls used in the food industry: steel hall with sandwich panels, classic brick hall with a steel roof, prefabricated halls of reinforced concrete elements and prefabricated halls of ferrocement sandwich elements.

Analysis was carried out with the aim of reducing costs and respecting relevant environmental criteria. The data used in the analysis are real and calculated on the basis of material properties and structure of the analyzed object. According to the results of analysis, object which is recommended as a good compromise for investors from the aspect of cost reduction and preservation of the environment is prefabricated ferrocement hall. Such a result has justified from following reasons: with selection of prefabricated ferrocement hall financial savings at least 20\% financial savings have been made for the investor compared to the other three halls. Also considerable savings are visible in the usage of construction material as $30 \%$ less cement and $31 \%$ of steel is needed. Additional savings are made in the transportation and assemble phase due to the considerable less weight of the construction (at around 50\%). This type of hall can be recycled almost entirely and it provides savings in energy through entire life cycle of object: in the construction faze $30 \%$, exploitation $50 \%$, and recycling $50 \%$.

\section{Literature}

1. Antalová, L., Minarovièová, K. (2003): Evaluation of the acoustic properties of homogeneous and composite elements applied to partition wallsand doors, Slovak journal of civil engineering pg 38.

2. Cole, R. J. (1998): Energy and greenhouse gas emissions associated with the construction of alternative structural systems, University of British Columbia: Environmental research group.

3. Costner, P, (2005): Estimating Releases and Prioritizing Sources in the Context of the Stockholm Convention, International POPs Elimination Network, Mexico, 2005 Fires, U.S. Fire Administration, Topical Fire Research Series, Vol. 1, No. 18, pg. 10. 
4. DIN 4102-2 Fire Behavior of Building Materials and Building Components; Building Components; Definitions, Requirements and Tests, German Institute for Standardization.

5. Gorkum, C. (2010): $\mathrm{CO}_{2}$ emissions and energy consumption during the construction of concrete structures, Delft University of Technology, Holland, pg 4-3.

6. Flower, D.J., Sanjayan, J.G. (2007): Green House Gas Emissions due to Concrete Manufacture, Clayton, Australia.

7. Hawken, P., Lovins, A.B., Lovins, L.H. (2009): Natural capitalism: Creating the next industrial revolution, Boston, USA: Little, Brown and Company, pg. 119.

8. ISO 6946:2007 Building components and building elements -Thermal resistance and thermal transmittance- Calculation method, International Organization for standardization, Geneva.

9. Belgrade chamber of industry and commerce (2015): retrieved from http://www. kombeg.org.rs/Komora/udruzenja/UdruzenjePoljoprivrede.aspx?veza=1101

10. Papadopoulos, A., Karagiannidis, A.(2008),: Application of the multi-criteria analysis Method Electre III for the optimization of decentralized energy systems, Omega, 2008, pg. 39.

11. Perez-Lombard, L., Ortiz, J., Pout, C.(2008): A review on building energy consumption Information, Energy and Buildings, Vol. 40, No. 3, pg. 396.

12. Poel, B., Cruchten, G., Balaras, C.A. (2007): Energy performance assessment of existing dwellings, Energy and Buildings, Vol. 39, No. 4, pg. 400.

13. San-Jose, L. J.T., Cuadrado, R. J.(2010): Industrial building design stage based on a system approach to their environmental sustainability, Construction and Building Materials, Vol. 24, No. 4, pg. 440.

14. Sterner, E. (2002): Green procurement of buildings: A study of Swedish clients considerations, Construction Management and Economics, Vol. 20, No. 1,pg. 25.

15. Thomas Saaty, (1980): The Analytic Hierarchy Process: Planning, Priority Setting, Resource Allocation, McGraw-Hill

16. Thomas Saaty, (1986): Axiomatic foundation of the analytic hierarchy process, Management Science, Vol. 32, No. 7, pg. 849.

17. Kreijger, P., (1979): Energy analysis of materials and structures in the building industry, Applied Energy, pg. 17.

18. Law on planning and construction, ("Sl. glasnik RS", br. 72/2009, 81/2009 - ispr., 64/2010 - odluka US, 24/2011, 121/2012, 42/2013 - odluka US, 50/2013 - odluka US, 98/2013 - odluka US, 132/2014 i 145/2014 ) article 2- 36.

19. Law on planning and construction, ("Sl. glasnik RS", br. 72/2009, 81/2009 - ispr., 64/2010 - odluka US, 24/2011, 121/2012, 42/2013 - odluka US, 50/2013 - odluka US, 98/2013 - odluka US, 132/2014 i 145/2014 ) article 2- 36a.

20. Law on noise protection in the environment, ("Službeni glasnik RS", br. 36/2009 i 88/2010) article 3-1.

21. Law on noise protection in the environment, ("Službeni glasnik RS", br. 36/2009 i 88/2010) article 3-17. 


\title{
VIŠEKRITERIJUMSKI PRISTUP IZBORA TIPA INDUSTRIJSKIH HALA KORIŠĆENIH U PREHRAMBRENOJ INDUSTRIJI
}

\author{
Ozrislava Milinkovićc ${ }^{6}$ Branislav Jakić7 , Slobodan Vuksanovic ${ }^{8}$, Dragana Macura ${ }^{9}$, \\ Milica Šelmić ${ }^{10}$
}

\begin{abstract}
Abstrakt
Projektovanje proizvodnog pogona prehrambene industrije uključuje sve faze njegovog razvoja, od ideje i odabira tehnološkog procesa do izgradnje i puštanja u pogon. Ciljevi kojima se teži u odabiru i izgradnji višenamenskog industrijskog objekta su smanjenje troškova ali i negativnog uticaja koji objekat ima na životnu sredinu. Drugim rečima teži se povezivanju inženjerske teorije i prakse radi ostvarivanja uštede u korišćenju resursa potrebnih za izgradnju, smanjivanja troškova upotrebe i održavanja gledano iz ugla celog životnog ciklusa objekta. Uvođenje koncepta održivosti u prehrambenu inudstriju mora početi od odabira održivih postrojenja u kojima se obrađuje, pakuje i sladišti hrana. Ovo je važno jer u zagađenoj životnoj sredini nije moguća proizvodnja kvalitetne hrane. Primenom višekriterijumskih metoda odlučivanja omogućeno je objektivnije sagledavanje uticaja višenamenskih industrijskih objekata korišćenih u prehrambenoj industriji na životnu sredinu kao i njihovu sposobnost da ispune zadate proizvodne i ekološke kriterijume. Rad je posvećen analizi najčešće korišćenih industrijskih objekata-hala namenjenih prehrambenoj industriji i sistemima gradnje sa aspekta zaštite životne sredine i održivog razvoja.
\end{abstract}

Ključne reči: višenamenski industrijski objekti -hale, zaštita životne sredine, održivi razvoj, višekriterijumska optimizacija - analitički hijerarhijski proces.

6 Dr Ozrislava Milinković Univerzitet Privredna Akademija Novi Sad, Fakultet za primenjeni menadžment ekonomiju i finansije, Nemanjina 4, 11000 Beograd, Srbija +381 2643390 , E-mail: ozradjurovic@yahoo.com

7 Profesor, dr Branislav Jakić, Univerzitet Privredna Akademija Novi Sad, Fakultet za primenjeni menadžment ekonomiju finansije, Nemanjina 4, 11000 Beograd, Srbija +381 26 43 390, E-mail: branislav.jakic@mef.edu.rs

8 Docent, dr Slobodan Vuksanović, Univerzitet Privredna Akademija Novi Sad, Fakultet za primenjeni menadžment ekonomiju i finansije, Nemanjina 4, 11000 Beograd, Srbija +381 2643 390, E-mail: jassnna@yahoo.com

9 Docent, dr Dragana Macura, Univerzitet u Beogradu, Saobraćajni fakultet Vojvode Stepe 305, 11000 Beograd, Srbija, +381 11 3091286, E-mail: d.macura@sf.bg.ac.rs

10 Docent, dr Milica Šelmić, Univerzitet u Beogradu, Saobraćajni fakultet Vojvode Stepe 305, 11000 Beograd, Srbija, +381 11 3091286, E-mail: m.selmic@sf.bg.ac.rs 
ECONOMICS OF

AGRICULTURE

\section{CONTENT}

1. Željko Anđelković, Aleksandra Dragin, Sanja Božić, Kristina Košić

EMOTIONAL EXHAUSTION AND JOB SATISFACTION OF TOUR GUIDES IN RURAL AREAS . . . . . . . . . . . . . . 11

2. Sanja Đukić, Danica Glavaš-Trbić, Nikola Banjac

MANAGEMENT PROBLEMS OF RURAL DEVELOPMENT IN FRUŠKA GORA . . . . . . . . . . . . . . . . . . . . 27

3. Ivana Ilić, Bojan Krstić, Sonja Jovanović

ENVIRONMENTAL PERFORMANCES OF AGRICULTURE IN THE EUROPEAN UNION COUNTRIES . . . . . . . . . . . . . 41

4. Nataša Kljajić, Jonel Subić, Zorica Sredojević

PROFITABILITY OF RASPBERRY PRODUCTION

ON HOLDINGS IN THE TERRITORY OF ARILJE. . . . . . . . . . . 57

5. Aleksandar Maksimović, Zoran Grgić, Ferhat Ćejvanović

MULTI-ATTRIBUTE ANALYSIS OF ORCHARD ACCORDING

TO THE INTEGRATED PRODUCTION CONCEPT . . . . . . . . . . 69

6. Ozrislava Milinković, Branislav Jakić, Slobodan Vuksanović,

Dragana Macura, Milica Šelmić

MULTI- CRITERIA DECISION BASED APPROACH

TO SELECTING THE TYPE OF INDUSTRIAL HALLS

USED IN FOOD INDUSTRY $\ldots \ldots \ldots \ldots$. . . . . . . . . . 81

7. Gordana Nikić, Ljubiša Stamatović, Azra Sućeska

EMOTIONAL COMPETENCIES AND PERSONALITY

TRAITS OF MANAGERS IN MODERN AGROBUSINESS. . . . . . . .97

8. Vladimir Obradović, Nemanja Karapavlović

FINANCIAL REPORTING OF COMPREHENSIVE INCOME

IN THE FOOD AND BEVERAGE SECTOR

IN THE REPUBLIC OF SERBIA . . . . . . . . . . . . . . 113 
9. Aleksandar Ostojić, Nebojša Savić, Željko Vaško

CONSUMER ATTITUDES

ON BUYING FISH IN BANJA LUKA . . . . . . . . . . . . . . . 129

10. Radivoj Prodanović, Boris Kuzman, David Jovović, Lazar Ozegović

MARKET AND TRADE OF ORGANIC FRUITS IN SERBIA $\ldots . . .141$

11. Predrag Vukadinović, Aleksandar Damnjanović, Ljiljana Dimitrijević

ANALYSIS OF THE SALES AND INCOMES BETWEEN

DIFFERENT CATEGORIES OF AGRICULTURAL PRODUCTS . . . 157

12. Jugoslav Aničić, Svetlana Vukotić, Goran Maksimović

THE POSSIBILITIES AND LIMITATIONS

OF ENTREPRENEURSHIP DEVELOPMENT

IN AGRICULTURE IN SERBIA . . . . . . . . . . . . . . 171

13. Željko Bjelajac, Marijana Dukić - Mijatović, Joko Dragojlović

FOOD SAFETY AS ONE OF THE MAIN SAFETY $P$

REOCCUPATIONS OF A MODERN MAN . . . . . . . . . . . . . 191

14. Milan Bradić, Ljiljana Kosar, Lukrecija Djeri, Svetlana Vukosav, Vuk Garača

ECO-LABELLING OF ACCOMMODATION FACILITIES

AND ITS PERCEPTION BY RURAL TOURISTS:

CASE STUDY OF VOJVODINA . . . . . . . . . . . . . . 205

15. Vaso Jegdić, Iva Škrbić, Srđan Milošević

MODELS OF ENTREPRENURSHIP DEVELOPMENT

IN RURAL TOURISM DESTINATIONS IN VOJVODINA . . . . . . . 221

16. Duško Kuzović

MUSEUM OF VERNACULAR ARCHITECTURE OF WESTERN SERBIA

- Representative curtilages of the area surrounding middle

course of the river Drina and Podgorina . . . . . . . . . . . 239

17. Branko Mihailović, Zoran Simonović, Nikola Ćurčić

AGRICULTURAL RESOURCES AND DEVELOPMENT

PRIORITIES OF THE MUNICIPALITY OF STARA PAZOVA. . . . . 259

18. Radmilo Nikolić, Aleksandra Fedajev, Vidoje Stefanović, Silvana Ilić

THE AGRICULTURE SECTOR IN WESTERN BALKANS

- SOME CHARACTERISTICS OF DEVELOPMENT. . . . . . . . . . 275

19. Vladimir Njegomir, Rajko Tepavac, Nenad Ivanišević

ALTERNATIVE SOURCES OF FINANCING

ENTREPRENEURIAL UNDERTAKINGS IN AGRICULTURE . . . 295

Economics of Agriculture, Year 64, No. 1 (1-404) 2017, Belgrade 
20. Daniela Nuševa, Kristina Mijić, Dejan Jakšić

THE PERFORMANCES OF COFFEE PROCESSORS

AND COFFEE MARKET IN THE REPUBLIC OF SERBIA . . . . . . 307

21. Svetlana Roljević Nikolić, Predrag Vuković, Biljana Grujić

MEASURES TO SUPPORT THE DEVELOPMENT OF ORGANIC

FARMING IN THE EU AND SERBIA . . . . . . . . . . . . 323

22. ŽeljkoVojinović, Vera Zelenović, DragoCvijanović

PROGRAM OF STATE SUPPORT

TO AGRICULTURAL CREDITING. . . . . . . . . . . . . . . . 339

23. Nikola Vuksanović, Dragan Tešanović, Bojana Kalenjuk,

Milijanko Portić, Marija Knežević

SOCIO-DEMOGRAPHIC CHARACTERISTICS

AS DETERMINANTS OF DIFFERENCES

IN PERCEPTION OF LOCAL GASTRONOMY . . . . . . . . . . . . 359 